\title{
Pengaruh Gambar dan Profil Instagram Terasrumahmu terhadap Kesadaran Merek
}

\author{
Natalia Ayu Widyawati Tukau \\ Jurusan Ilmu Komunikasi, Universitas Atma Jaya Yogyakarta \\ Jl. Babarsari No.43, 55281, Indonesia \\ Corresponding author: natalia.nayu@gmail.com
}

\begin{abstract}
This study aims to analyze the relationship between Instagram quality and brand awareness. There are two dimensions to Instagram quality, namely the quality of the message content and the credibility of the endorser. This study tested the Meaning Transfer Model. This research method uses quantitative explanative with survey data collection techniques. The sample used by the researchers amounted to 201 respondents who came from visitors to the English Ivy Coffee café. The results of this study indicate that Terasrumahmu has successfully carried out marketing communications via Instagram. The quality of message content has the strongest relationship with brand awareness where the quality of message content has a correlation of 0.614 while endorser credibility is 0.557 . These results indicate a positive and significant relationship between Instagram quality and brand awareness among Terasrumahmu Instagram users at the English Ivy Coffee cafe. Consumer characteristics such as age and gender also need to be considered, where age has a correlation of 0.737 while the male gender is 0.755 , and the female gender is 0.615 , which means that aspects of male consumer characteristics have the strongest influence on the relationship between Instagram quality and brand awareness. The contribution of this research is the need to add a variable color sharpness of photos and informative profiles so that respondents are able to recognize and remember products so that they are top of mind.
\end{abstract}

Keywords: Instagram; Endorser's Credibility; Marketing Communication; Model of Brand Awareness; Transfer of Meanings

Abstrak
Penelitian ini bertujuan untuk menganalisis hubungan antara kualitas Instagram dengan kesadaran merek. Terdapat dua dimensi dalam kualitas Instagram yakni kualitas konten pesan dan kredibilitas endorser. Penelitian ini menguji Model Pemindahan Makna. Metode penelitian ini menggunakan eksplanatif kuantitatif dengan teknik pengumpulan data survei. Sampel yang digunakan oleh peneliti berjumlah 201 responden yang berasal dari pengunjung café English Ivy Coffee. Hasil penelitian ini menunjukkan jika Terasrumahmu telah berhasil melakukan komunikasi pemasaran melalui Instagram. Kualitas konten pesan memiliki hubungan paling kuat dengan kesadaran merek di mana kualitas konten pesan memiliki korelasi 0,614 sedangkan kredibilitas endorser 0,557 . Hasil ini menunjukkan terdapat hubungan positif dan signifikan antara kualitas Instagram dengan kesadaran merek di kalangan pengguna Instagram Terasrumahmu di kafe English Ivy Coffee. Karakteristik konsumen seperti usia dan jenis kelamin juga perlu diperhatikan di mana usia memiliki korelasi 0,737 sedangkan jenis kelamin laki-laki 0,755 dan jenis kelamin perempuan 0,615 yang berarti aspek karakteristik konsumen laki-laki memberi pengaruh paling kuat pada hubungan antara kualitas Instagram dengan kesadaran merek. Kontribusi penelitian ini berupa perlunya penambahan variabel ketajaman warna foto dan profil yang informatif sehingga responden mampu mengenali dan mengingat produk agar top of mind. Kata kunci: Instagram; Kredibilitas Endorser; Komunikasi Pemasaran; Model Kesadaran Merek; Pemindahan Makna

\section{Pendahuluan}

Saat ini perkembangan teknologi digital semakin pesat dan secara umum kehidupan manusia tidak dapat terlepas dari perangkat yang serba elektronik khususnya penggunaan media sosial (Setiawan, 2017). Berdasarkan
Essential Insights Into Internet, Social Media, Mobile and E-Commerce Use Around The World menyatakan bahwa dari total populasi Indonesia sebanyak 265,4 juta jiwa, pengguna aktif media sosial mencapai 130 juta dengan penetrasi 49 persen (Pertiwi, 2018). 
Media sosial telah menjadi sarana bagi konsumen dalam berbagi informasi teks, gambar, audio dan video. Penggunaan media sosial juga diakui dapat mendongkrak kinerja bisnis karena pemasar mampu berinteraksi dengan konsumen serta membangun hubungan baik (Kotler, 2012). Pemasaran melalui media sosial juga tidak hanya ditujukan pada perusahaan besar, perusahaan kecil dan menengah kini telah memanfaatkannya penggunaannya sehingga sosial media dianggap tidak hanya pemasaran namun menjadi cara paling efektif dalam menjalankan bisnis (Dewi \& Avicenna, 2019). Penelitian yang dilakukan oleh Sjöberg (2017) menyatakan kata-kata melalui elektronik memiliki korelasi positif dengan kesadaran merek. Hal ini menunjukkan jika media sosial dapat memberikan kesadaran merek atau brand awareness kepada konsumen.

Salah satu media sosial yang paling banyak digunakan saat ini adalah Instagram. Dilansir dari digitalentrepreneur.id menyatakan secara keseluruhan jumlah pengguna aktif bulanan Instagram telah mencapai kisaran 800 juta (Putri, 2018). Angka pengguna Instagram yang tinggi pula memberikan peluang kepada pemasar dalam memasarkan produk melalui Instagram.

Maraknya penggunaan Instagram sebagai media pemasaran menuntut pemasar harus mengetahui cara menggunakan Instagram agar lebih berkualitas. Ada beberapa cara agar Instagram dapat dikatakan berkualitas yaitu pertama kualitas konten pesan. Seorang pemasar memerlukan format pesan yang jelas jika ingin menarik perhatian konsumen. Format pesan tersebut seperti ketika dipasarkan melalui iklan cetak maka perlu memperhatikan judul, gambar, cetakan, dan warna (Machfoedz, 2010). Format pesan yang digunakan dalam penelitian inimelalui media sosial salah satunya adalah Instagram.

Instagram memiliki dua cara untuk menciptakan konten pesan yang berkualitas yang pertama penggunaan foto yang menarik. Gambar di Instagram dapat mempengaruhi pikiran dan perasaan konsumen sehingga memutuskan untuk membeli (Nummila, 2015). Nummila menyebutkan sebelum memposting gambar, pengguna akun dapat meningkatkan kualitas gambar dengan menggunakan fiturfitur yang ada seperti menambah ketajaman warna maupun memfokuskan gambar yang akan ditampilkan di Instagram (Nummila, 2015).

Kualitas konten pesan kedua adalah Instagram dianggap berkualitas jika memiliki profil yang informatif. Profil harus mendukung nilai, visi dan misi bisnis agar konsumen dapat lebih mudah mengenal halaman profil. Gambar profil juga harus berupa foto prefesional dengan menggunakan logo perusahaan (Nummila, 2015).

Pada profil terdapat beberapa hal yang harus diperhatikan. Menurut Later dan HubSpot (2018) yang harus diperhatikan di dalam profil yaitu pertama pemasar harus membuat nama yang familier agar mudah untuk ditemukan. Pada profil yang harus diperhatikan adalah kata kunci. Kata kunci membuat pengikut memahami pemilik akun serta yang ditawarkan oleh pemasar. Profil juga harus memiliki bagian ketiga yakni alamat email. Pemasar wajib menyertakan alamat email agar konsumen mudah mencari informasi mengenai produk. Profil juga wajib memiliki bagian keempat yaitu hashtag atau tagar produk. Profil Instagram juga harus menyertakan hashtag agar gambar mendapatkan jangkauan yang maksimal saat mempromosikan produk karena melalui hashtag produk akan mendapatkan perhatian dari konsumen (Nummila, 2015).

Kualitas Instagramjugawajibmemperhatikan kredibilitas endorser. Kredibilitas merupakan kostruksi berbasis penerima karena kredibilitas ada pada persepsi seseorang yang melihatnya (Seiter \& Gass, 2003) sedangkan endorser adalah orang yang sebagian besar diakui oleh publik dan menggunakan identifikasi ini untuk mendukung produk dalam iklan (Roy, Jain, \& Rana, 2013).

Kredibilitas endorser memiliki beberapa hal yang harus diperhatikan adalah attractiveness atau daya tarik. Endorser yang menarik diyakini memiliki dampak positif pada produk 
dibandingkan dengan yang kurang menarik (Sertoglu, Cath, \& Korkmaz, 2014). Daya tarik atau attractiveness yang diteliti dalam penelitian ini seperti berkelas, tidak berkelas, cantik, atau tidak cantik, anggun dan tidak anggun, seksi atau tidak seksi (Seiter \& Gass, 2003).

Pemasar juga perlu memperhatikan kredibilitas kedua yaitu tingkat kepercayaan atau trustworthiness. Kepercayaan didefinisikan sebagai kejujuran dan integritas (Sertoglu, Cath, \& Korkmaz, 2014). Menurut Ohanian (Stephanie, 2013) pemasar dianjurkan memilih endorser yang memiliki expertise dan trustworthiness secara bersamaan. Expertise mengacu pada tingkat pengetahuan tentang subjek, maka trustworthiness merujuk pada kejujuran dan sifat bisa dipercaya dari sumber. Dimensi trustworthiness atau kepercayaan dapat dilihat dari jujur atau tidak jujur dan dapat dipercaya atau tidak dapat dipercaya (Stephanie, 2013).

Kredibilitas endorser yang ketiga yakni endorser harus memiliki expertise atau keahlian. Keahlian adalah sejauh mana endorser dianggap memiliki pengetahuan yang memadai, pengalaman atau ketrampilan untuk mempromosikan produk. Keahlian endorser adalahsejauhmanakomunikatordianggapsebagai sumber pernyataan yang valid. Dimensi expertise atau keahlian dapat dilihat dari pengalaman atau tidak pengalaman, informatif atau tidak informatif (Sertoglu, Cath, \& Korkmaz, 2014).

Pemasar juga harus mengetahui kredibilitas endorser yang keempat yakni similarity atau kesamaan. Kesamaan yang dimaksud dapat berupa usia, pekerjaan, sikap, fisik, pendapatan, pendidikan, dialek bicara, kepribadian, etnis, afiliasi politik, gaya interpersonal, preferensi pakaian dan seterusnya (O’Keefe, 2016). Dalam penelitian ini peneliti menggunakan dimensi usia, fisik, dan budaya.

Penjelasan mengenai kualitas Instagram menunjukkan jika terdapat dua dimensi penting yang harus diperhatikan pemasar ketika menggunakan Instagram sebagai media pemasarannya. Pertama memperhatikan kualitas konten pesannya yang terdiri dari foto dan profil dan kedua memperhatikan kredibilitas endorser yang memiliki attractiveness, trustworthiness, expertise dan similarity. Peneliti tertarik untuk menganalisishubungankualitas Instagramdengan kesadaran merek. Penelitian ini pernah dilakukan oleh Sa'diya (2017) yang menyatakan bahwa foto dan video yang diunggah ke Instagram dapat menarik perhatian konsumen dan disebutkan jika semakin seringnya foto tersebut diposting maka akan semakin sering dilihat oleh generasi $\mathrm{Z}$ yang pada akhirnya akan mencapai kesadaran merek (Sa'diya, 2017). Hasil dari penelitian Sa'diya peneliti jadikan acuan untuk melihat hubungan kualitas Instagram dengan kesadaran merek pada tahun dan objek yang berbeda.

Mengacu pada penelitian yang pernah dilakukan oleh Shojaee dan Bin Azman (Sjöberg, 2017) menyatakan kata-kata melalui elektronik memilikikorelasipositifdengankesadaranmerek. Berdasarkan penelitian Bin Azman inilah peneliti merasa penting untuk menganalisis penelitian mengenai penggunaan media sosial yang saat ini paling banyak digunakan yakni Instagram. Katakata melalui elektronik peneliti lihat dari cara penggunaan Instagram melalui dengan kualitas konten pesan dan kredibilitas endorser yang biasa digunakan pemasar dalam memunculkan kesadaran merek pada konsumennya.

Penggunaan kualitas Instagram dengan baik dan benar membentuk kesadaran merek pada konsumen. Fauzi dan Lubis (2016) menyatakan jika kesadaran merek atau brand awareness adalah kemampuan seorang konsumen untuk mengenali atau mengingat kembali suatu merek yang bergantung pada tingkat komunikasi atau persepsi pelanggan terhadap merek produk yang ditawarkan.

Kesadaran merek memiliki empat indikator yang terdiri dari unaware of brand atau tingkat paling rendah dalam piramida kesadaran merek di mana konsumen tidak menyadari adanya suatu merek. Kesadaran merek kedua brand 
recognition adalah pengenalan suatu merek muncul lagi setelah dilakukan pengingatan kembali lewat bantuan. Kesadaran merek ketiga, brand recall yaitu pengingatan kembali terhadap merek tanpa bantuan. Kesadaran merek keempat, top of mind yakni merek yang disebut pertama kali oleh konsumen atau yang pertama kali muncul di dalam benak (Durianto, 2001).

Salah satu usaha yang menggunakan Instagram untuk membentuk brand awareness kepada konsumen adalah clothing bermerek Terasrumahmu. Terasrumahmu merupakan suatu usaha yang dibentuk pada tahun 2017 dengan mengusung konsep tulisan singkat seperti hitam manis yang dituliskan ke baju, gantungan kunci maupun tas. Terasrumahmu memasarkan produknya melalui Instagram dengan memaksimalkan konten Instagram seperti foto atau video maupun menggunakan endorser.

Feby Ampangallo sebagai founder Terasrumahmu menyebutkan Instagram menjadi salah satu media yang paling efektif karena dapat menjangkau khalayak luas. Hal ini terbukti dari jumlah followers Terasrumahmu sebanyak 221 ribu. Perkembangan usaha Terasrumahmu fokus membuat konten yang menarik melalui Instagram dan memaksimalkan penggunaan endorser. Terasrumahmu memaksimalkan Instagramnya dengan mengatur foto produk agar lebih menarik, menggunakan endorser seperti Conchita Caroline pemain FTV maupun selebgram seperti Rachel Vennya. Langkah tersebut merupakan cara pemasar mengemas sebuah pesan persuasi melalui Instagram dengan membuat konten pesan yang menarik maupun menggunakan endorser yang menarik. Hal inilah yang menjadi alasan bagi peneliti menggunakan Terasrumahmu sebagai objek yang diteliti karena telah memanfaatkan penggunaan Instagram dari dimensi kualitas konten pesan dan kredibilitas endorser.

Gambar 1 memperlihatkan Terasrumahmu fokus pada gambar produk dan tulisan yang menjadi ciri khasnya. Gambar 1 juga memperlihatkan profil yang terdiri dari nama merek maupun link tautan untuk menghubungkan konsumen pada pemesanan produk melalui Whatsapp, Tokopedia, maupun Line. Informasi yang lengkap pada profil ini tentu sangat membantu konsumen dalam memahami dan mengenal merek yang pemasar tawarkan.

Gambar 2 memperlihatkan Conchita Carolina Rajasa menjadi salah satu endorser yang dipilih oleh Terasrumahmu untuk mengenalkan
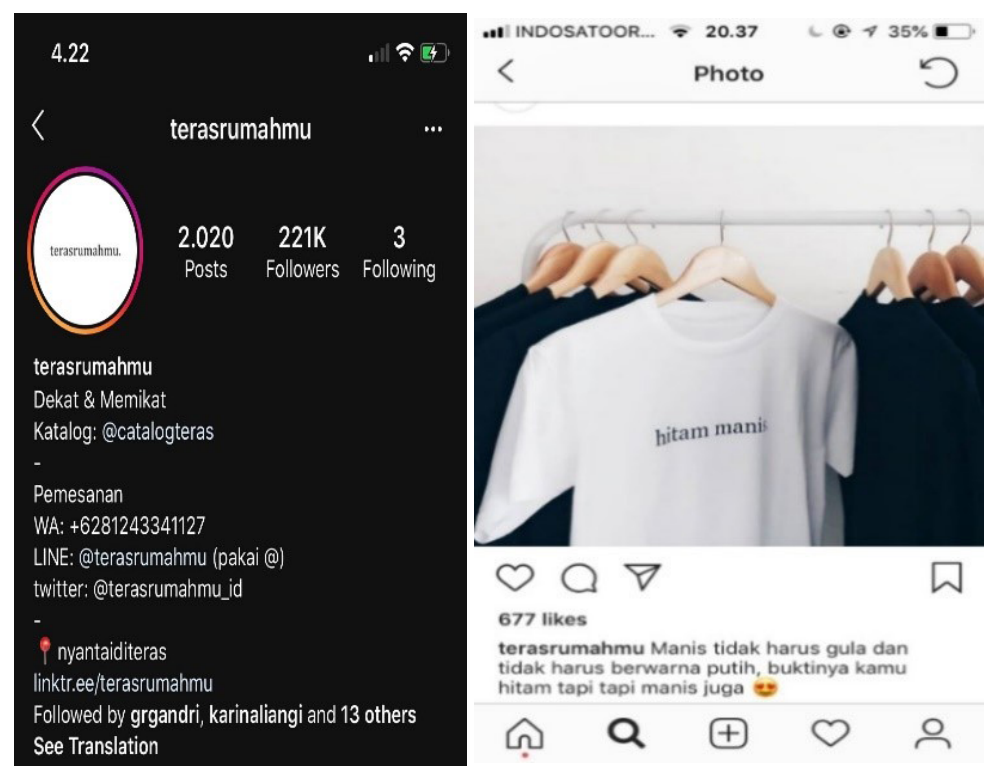

Gambar 1. Gambar Produk dan Profil Terasrumahmu

Sumber: Instagram @terasrumahmu (2020) 


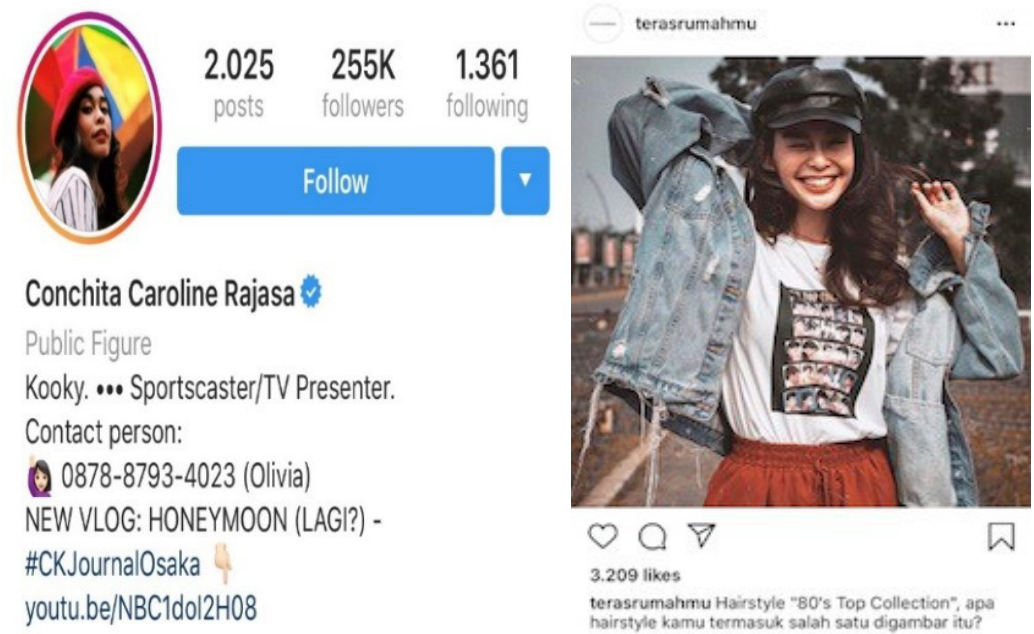

Gambar 2. Endorser Terasrumahmu

Sumber: Instagram @terasrumahmu (2020)

produknya kepada konsumen. Caroline merupakan seorang artis maupun selebgram terkenal di Indonesia yang juga memiliki jumlah pengikut yang tercatat di tahun 2020 sudah mencapai 482 ribu orang. Jumlah pengikut yang cukup banyak tentu memberikan pengaruh semakin dikenalnya produk Terasrumahmu sehingga mampu menimbulkan kesadaran merek yang top of mind bagi konsumen.

Terasrumahmu telah mencoba memaksimalkan penggunaan Instagram sebagai media pemasarannya dan terdapat salah satu penelitian yang dilakukan oleh (Yudhiartika \& Haryanto, 2012) dengan judul "Pengaruh Personal Selling, Display, Promosi Penjualan terhadap Kesadaran Merek dan Intensi Membeli pada Produk Kecantikan Pond's". Hasil penelitian tersebut menyatakan media sosial seperti Instagram tidak selamanya dapat memberikan pengaruh yang kuat pada kesadaran merek. Hasil temuan Yudhiartika dan Haryanto inilah yang membuat peneliti melakukan analisis mengenai hubungan antara kualitas Instagram dengan kesadaran merek yang juga mengacu pada penelitian Sa'diya yang menyebutkan jika foto dan video memberi pengaruh pada kesadaran merek dan seringnya mengunggah foto atau video ke Instagram dapat menarik perhatian konsumen sehingga sampai pada tataran terciptanya kesadaran merek yang top of mind (Sa'diya, 2017). Penelitian Yudhiartika dan Haryanto dilakukan pada tahun 2012 sedangkan penelitian ini dilakukan tahun 2019 dan objek yang digunakan dalam penelitian juga berbeda. Hasil penelitian ini memberikan kebaruan pada ilmu pemasaran dan juga mendukung pernyataan Kotler bahwa media sosial sungguh dapat mendongkrak kinerja bisnis asalkan tetap memperhatikan aspek kualitas konten pesan maupun memilih endorser yang kredibel.

Penelitian terdahulu yang juga menjadi acuan dari penelitian ini yaitu penelitian yang dilakukan oleh Pattra \& Datta, (2014) dengan judul "Competence of Bollywood Celebrities in Generating Brand Recall in Kolkata" Penelitian tersebut melihat peran selebriti India dalam menghasilkan kesadaran merek dan pilihan merek. Hasil penelitian tersebut menyatakan jika "Q" dari selebriti Bollywood tidak memiliki hubungan pada kesadaran merek tetapi memainkan peran positif dalam menghasilkan preferensi merek pada responden pria dan wanita di Kolkata. Skor "Q" menunjukkan dua hal yaitu responden pernah melihat atau mendengar selebriti yang dipilih, jika iya maka responden menilai dari skala one of my favourite, very good, good, fair or poor. 
Perbedaan penelitian tersebut dengan penelitian ini adalah penelitian Pattra \& Datta menyatakan jika peran selebriti tidak memiliki hubungan pada kesadaran merek melainkan memberikan preferensi merek dan hasil penelitian peneliti menunjukkan jika kredibilitas endorser yang digunakan Terasrumahmu memiliki hubungan pada kesadaran merek dengan memiliki korelasi 0,557 begitu pula dengan kualitas konten pesan Instagram memiliki hubungan dengan kesadaran merek dan korelasinya 0,614. Jumlah korelasi ini menunjukkan jika kualitas konten pesan memiliki hubungan yang kuat jika dibandingkan dengan kredibilitas endorser. Kesamaan dari kedua penelitian ini samasama menggunakan jenis penelitian kuantitatif.

Penelitian kedua dilakukan oleh Nummila (2015) dengan judul "Successful Social Media Marketing on Instagram". Case:@Minoshoes. Hasil penelitian tersebut menunjukkan setiap perusahaan menggunakan Instagram sebagai media pemasarannya. Penggunaan Instagram juga jauh lebih rileks dan komunikasi antara konsumen dan perusahaan dapat dilakukan dengan dua arah. Hal yang paling menarik untuk mengukur Instagram adalah tingkat keterlibatan melalui komentar yang dapat berpengaruh pada pengguna lainnya. Perbedaan penelitian yang dilakukan oleh Nummila dengan penelitian ini adalah penelitian Numilla bersifat kualitatif dan hanya melihat kesuksesan pemasaran media melalui Instagram. Subjek dalam penelitian ini adalah@Minoshoes yang juga dibandingkan dengan perusahaan HnM sedangkan hasil penelitian peneliti menyebutkan jika penggunaan Instagram dikatakan berkualitas jika menggunakan dua dimensi yaitu kualitas konten pesan dan kredibilitas endorser. Hasilnya bahwa dimensi kualitas konten pesan yang terdiri dari foto dan profil memberi hubungan paling kuat dengan kesadaran merek jika dibandingkan dengan kredibilitas endorser. Penelitian ini juga memberi kebaruan jika keberhasilan Instagram tidak hanya bisa diukur dengan banyaknya keterlibatan konsumen dengan menulis di kolom komentar Instagram melainkan aspek foto yang menarik serta profil yang informatif juga perlu diperhatikan. Kesamaan kedua penelitian ini adalah adalah sama-sama meneliti Instagram sebagai media pemasaran.

\section{Komunikasi Pemasaran}

Komunikasi pemasaran adalah sarana yang digunakan perusahaan dalam upaya untuk menginformasikan, membujuk, dan mengingatkan konsumen baik secara langsung maupun tidak langsung tentang produk dan merek yang pemasar jual (Kotler, 2012). Teori utama dalam penelitian ini dilihat dari tiga hal yaitu adanya keterlibatan, komunikasi pemasaran harus berpusat pada audiens, dan adanya respon kognitifatau hal yang mengacu pada keberhasilan dari komunikasi pemasaran (Jamieson dan Fill, 2014). Komunikasi pemasaran menggunakan media sosial menjadi sarana bagi konsumen untuk berbagi informasi teks, gambar, audio, dan video dengan satu sama lain dengan perusahaan dan sebaliknya. Peran media sosial juga diakui dapat mendongkrak kinerja bisnis karena pemasar mampu berinteraksi dengan konsumen serta membangun hubungan yang baik (Kotler, 2012). Komunikasi pemasaran diartikan sebagai suatu usaha untuk menyampaikan pesan kepada publik terutama konsumen mengenai keberadaan produk di pasar dengan memerhatikan kualitas konten (Arniawati, Sutrisno, \& Rochayanti, 2015).

\section{Kualitas Konten Pesan}

Seorang pemasar memerlukan format pesan yang jelas saat ingin menarik perhatian konsumen. Format pesan yang dimaksud adalah ketika ingin memasarkan melalui iklan cetak maka perlu memperhatikan judul, gambar, cetakan dan warna (Machfoedz, 2010). Format pesan yang dimaksud oleh Machfoedz pada penelitian tersebut adalah kualitas konten pesan melalui Instagram. Saat ini para pengguna Instagram memilih membuat konten yang 
menarik agar menjadi perhatian khalayak dibandingkan dengan konten yang tidak menarik (Destriyani, Fatonah, Sutrisno, 2019). Faktor yang membuat konten foto lebih terlihat menarik adalah dengan mengatur sudut pengambilan gambar seperti dari atas dan depan, pencahayaan, latar belakang gambar, menggunakan properti dan menambah resolusi foto agar lebih terlihat menarik (Destriyani, Fatonah, \& Sutrisno, 2019). Pernyataan yang sama juga dijelaskan bahwa pada saat memposting gambar pengguna Instagram dapat meningkatkan kualitas gambar seperti mempertajam fokus gambar maupun memberi efek terang pada gambar (Nummila, 2015). Kualitas konten pesan kedua adalah profil Instagram merupakan informasi yang diperlukan oleh konsumen dan dalam profil terdapat beberapa hal yang perlu diperhatikan seperti nama, kata kunci, email, dan hashtag produk (Nummila, 2015).

\section{Kredibilitas Endorser}

Instagram dapat dikatakan berkualitas jika memiliki kredibilitas endorser yang baik. Terdapat empat dimensi kredibilitas endorser. Pertama attractiveness atau daya tarik. Komunikator yang menarik lebih disukai dan diyakini memiliki dampak positif pada produk jika dibandingkan dengan yang tidak menarik (Sertoglu, Catlh, \& Korkmaz, 2014). Dimensi attractiveness dapat dilihat dari berkelas tidak berkelas, cantik tidak cantik, anggun tidakanggun, seksi atau tidak seksi (Seiter \& Gass, 2003).

Dimensi kredibilitas endorser kedua adalah trustworthiness atau tingkat kepercayaan. Trustworthiness merupakan cara mempersuasi atau kemampuan keahlian yang dimiliki endorser (Sertoglu, Catlh, \& Korkmaz, 2014). Dimensi trustworthiness dilihat dari jujur tidak jujur, dipercaya atau tidak dapat dipercaya (Seiter \& Gass, 2003). Dimensi kredibilitas endorser ketiga yaitu expertise atau keahlian yang merujuk pada pengetahuan komunikator yang nampak dari pernyataan yang disampaikan ketika memasarkan produk (Korkmaz, Sertoglu, Catli, 2014). Dimensi expertise dilihat dari pengalaman atau tidak pengalaman, informatif atau tidak informatif (Seiter \& Gass, 2003). Dimensi kredibilitas keempat similarity atau kesamaan merupakan hal yang tercermin saat meyakinkan konsumen mengenai kesamaan antara pembicara dengan konsumen. Kesamaan yang dilihat dari endorser dengan konsumen seperti usia, pekerjaan, pendapatan, sikap, fisik, etnis, kepribadian, yata interpersonal (O'Keefe, 2016).

\section{Model Pemindahan Makna}

Kredibilitas endorser juga terdapat model pemindahan makna yang menyebutkan selebriti memiliki peran dalam masyarakat karena digambarkan oleh media dalam mengembangkan citra endorser (Bell, 2012). Model pemindahan makna juga menyebutkan jika seorang celebrity endorser yang mengenalkan produk kepada konsumen sangat terbantu dengan status yang dikenal oleh masyarakat luas. Seorang endorser yang dikenalnya oleh masyarakat memberikan makna tertentu dan tersalurkan dalam merek atau produk (Sertoglu, Cath, \& Korkmaz, 2014). Kemampuan endorser seperti kepercayaan atau trustworthiness dan keahlian atau expertise dapat mempengaruhi keyakinan dan sikap konsumen. Hal ini menjadi model transfer makna pesan persuasi bagi konsumen (Miller \& Allen, 2012).

\section{Kesadaran Merek atau Brand Awareness}

Kesadaran merek atau brand awareness adalah kekuatan dari suatu brand di dalam memori dan seberapa mudah bagi konsumen untuk mengingat suatu brand (Fauzi \& Lubis, 2016). Terdapat empat indikator untuk melihat seberapa jauh konsumen aware terhadap sebuah brand. Pertama unaware of brand yaitu konsumen tidak menyadari adanya suatu merek, kedua brand recognition adalah kesadaran merek di mana pengenalan suatu merek muncul lagi setelah dilakukan pengingatan kembali lewat bantuan, ketiga brand recall atau pengingatan 
kembali terhadap merek tanpa bantuan dan keempat top of mind yakni merek disebut pertama kali oleh konsumen atau pertama kali muncul dalam benak konsumen (Durianto, 2001). Kesadaran merek juga dapat dibangun dengan karakter dan karisma yang kuat. Hal ini dilakukan karena pada era digital pola perilaku konsumen berubah karena adanya percepatan dalam arus informasi (Nugraha \& Wahid, 2018).

Berdasarkan latar belakang dan tinjauan pustaka, penelitian ini bertujuan untuk menganalisis hubungan antara kualitas Instagram dengan kesadaran merek dan menganalisis pengaruh usia dan jenis kelamin pada hubungan antara kualitas Instagram dengan kesadaran merek. Penelitian ini diharapkan dapat memberi gambaran lebih jelas mengenai hubungan antara kualitas konten pesan dan kredibilitas endorser dari Terasrumahmu yang akan membuat konsumen top of mind pada produknya.

\section{Metode Penelitian}

Penelitian ini merupakan penelitian kuantitatif dengan tataran analisis eksplanatif. Metode yang digunakan adalah survei dan teknik pengumpulan data melalui kuesioner diberikan kepada yang berumur 17 sampai 25 tahun. Populasi dalam penelitian ini diambil dari segmentasi Terasrumahmu yakni berumur 17 sampai 25 tahun dan berjenis kelamin laki-laki dan perempuan. Pemilihan populasi berdasarkan segmentasi dari Terasrumahmu karena peneliti ingin melihat kesadaran merek anak-anak muda yang berumur 17 sampai 25 tahun pada Instagram Terasrumahmu. Pemilihan populasi tidak hanya yang mengikuti akun Instagram Terasrumahmu tetapi juga berlaku bagi yang tidak mengikuti akun Instagramnya.

Populasi penelitian ini berumur 17 sampai dengan 25 tahun, peneliti memilih salah satu café di Kota Yogyakarta tepatnya di jalan Sidomukti yang bernama English Ivy Coffee. Peneliti memilih kafe English Ivy Coffee karena dilansir dari salah satu berita online Brilio menyampaikan bahwa kafe tersebut merupakan tempat berkumpulnya anak-anak muda. Hal ini didasari dari tempatnya yang menarik dengan nuansa sawah, perkampungan serta bangunan yang unik membuat café ini menjadi instagramable untuk berfoto. Teknik sampling yang digunakan dalam penelitian ini adalah simple random sampling di mana pengambilan anggota sampel dari populasi dilakukan secara acak tanpa memperhatikan strata yang ada dalam populasi tersebut. Populasi dalam penelitian ini berjumlah 420 pengunjung. Data ini peneliti dapatkan dari pemilik cafe yang menyatakan jika jumlah pengunjung yang datang ke kafe English Ivy Coffee selama seminggu sekitar 400 sampai dengan 420 pengunjung. Melalui 420 pengunjung ini peneliti menggunakan tabel ukuran sampel untuk satu ukuran populasi tertentu yang menyatakan jika populasi sebanyak 420 orang maka sampel yang dapat digunakan mencapai 201 orang (Silalahi, 2015) oleh karena ini penelitian ini menggunakan 201 sampel untuk diberikan kuesioner. Data dikumpulkan melalui kuesioner. Variabel dalam penelitian ini terdiri dari kualitas Instagram (X) dengan kesadaran merek (Y). Variabel kualitas Instagram terbagi menjadi dua yaitu kualitas konten pesan (X) yang terdiri dari foto dan profil. Foto dilihat dari ketajaman warna gambar dan fokus sedangkan profil dilihat dari nama Instagram familier, Instagram memiliki kata kunci, Instagram menyertakan email, Instagram menyertakan hashtag. Variabel kedua adalah kredebilitas endorser (X) yang terdiri dari pertama, attractiveness atau daya tarik dapat dilihat dari berkelas tidak berkelas, cantik tampan atau tidak cantik atau tidak tampan, anggun tidak anggun dan seksi tidak seksi. Dimensi kredibilitas endorser kedua trustworthiness atau tingkat kepercayaan yang dilihat dari jujur tidak jujur, dapat dipercaya atau tidak. Dimensi kredibilitas endorser 
ketiga expertise atau keahlian dilihat dari pengalaman atau tidak pengalaman, informatif atau informatif. Dimensi kredibilitas endorser keempat similarity atau kesamaan dilihat dari kesamaan usia, fisik dan budaya. Kualitas konten pesan dan kredibilitas endorser menggunakan skala semantic diferensial. Skala ini berbentuk pilihan checklist dan jawaban dari sangat positif sampai dengan sangat negatif (Sugiyono, 2016).

Variabel kesadaran merek (Y) terbagi menjadi empat yaitu variabel pertama unaware of brand dilihat dari pengguna Instagram yang tidak mengenali merek Terasrumahmu, variabel kedua brand recognition dilihat dari pengguna Instagram mengenali merek dengan bantuan dan pengguna Instagram mengenali merek melalui logo maupun produk, variabel ketiga brand recall dilihat dari pengguna Instagram mampu mengingat merek diantara merek-merek lain tanpa bantuan dan variabel keempat top of mind dilihat dari pengguna Instagram mampu menyebutkan merek yang diketahui dalam benak. Dimensi kesadaran merek menggunakan skala Guttman dengan mengukur jawaban yang tegas di mana pemilih dapat menjawab ya atau tidak, benar atau salah (Sugiyono, 2016).

Hipotesis teoritik mayor penelitian ini adalah ada hubungan antara kualitas Instagram dengan kesadaran merek di kalangan pengguna Instagram Terasrumahmu. Hipotesis dimensi pertama ada hubungan antara kualitas konten pesan dengan kesadaran merek dan dimensi kedua ada hubungan antara kredibilitas endorser dengan kesadaran merek. Hipotesis penelitian mayor semakin tinggi kualitas Instagram semakin banyak yang top of mind. Hipotesis teoritik minor penelitian ini adalah ada hubungan antara kualitas Instagram dengan kesadaran merek dipengaruhi oleh usia dan ada hubungan antara kualitas Instagram dengan kesadaran merek dipengaruhi oleh jenis kelamin sedangkan hipotesis penelitian minor ada hubungan antara kualitas Instagram dengan kesadaran merek diperkuat oleh usia atau semakin tinggi usia maka makin kuat pengaruhnya pada hubungan kualitas Instagram dengan kesadaran merek dan ada hubungan antara kualitas Instagram dengan kesadaran merek diperkuat oleh jenis kelamin.

Teknik analisis data dalam penelitian ini menggunakan korelasi product moment untuk melihat besarnya hubungan antara kualitas Instagram dengan kesadaran merek. Uji validitas yang digunakan adalah dengan menguji setiap pertanyaan dari kualitas konten pesan dan kredibilitas endorser yang di mana hasilnya adalah valid. Pernyataan tersebut valid karena $r$ hitung $>r$ tabel di dapat dengan menggunakan rumus n-2 dan didapat hasil sebesar (201$2=199$.) Angka 199 ini lalu dicocokan pada tabel distribusi dan didapat angka 0,138 sedangkan reliabilitas dihitung menggunakan data yang diukur untuk masing-masing menghasilkan cronbach's alpha $>0,60$ jika sesuai maka data tersebut reliabel. Hasil uji validitas dan reliabilitas menyatakan jika kuesioner dalam penelitian ini adalah reliabel dan valid.

\section{Hasil Penelitian Dan Pembahasan}

Penyebaran kuesioner secara langsung dilakukan di kafe English Ivy Coffee dan diberikan kepada 201 pengunjung yang datang ke cafe tersebut. Selama hampir satu minggu peneliti menyebarkan kuesioner di lokasi penelitian dan kesulitan yang dialami selama menyebarkan kuesioner adalah banyaknya beberapa responden yang menolak ketika diberikan kuesioner dengan alasan sedang tengah mengobrol bersama teman-temannya.

Menganalisis hubungan antara kualitas Instagram dengan kesadaran merek. Variabel $\mathrm{X}$ terdiri dari kualitas Instagram yang diteliti dari dua dimensi yaitu aspek kualitas konten pesan yang dilihat dari foto dan profil. Dimensi kedua kredibilitas endorser yang dilihat dari attractiveness, trustworthiness, expertise, dan similarity sedangkan variabel $\mathrm{Y}$ terdiri dari kesadaran merek dilihat dari dimensi unaware of brand, brand recognition, brand recall, top of mind . 
Tabel 1. Korelasi antara Kualitas Instagram dan Dimensi Kualitas Konten Pesan maupun Kredibilitas Endorser

\begin{tabular}{lc}
\hline $\begin{array}{c}\text { Hubungan Kualitas Instagram dengan } \\
\text { Kesadaran Merek }\end{array}$ & Korelasi \\
\hline Kualitas Instagram & $\mathrm{r}=0,769$ \\
Dimensi Kualitas Konten Pesan & Sig. 0,000 \\
& $\mathrm{r}=0,614$ \\
Dimensi Kredibilitas Endorser & Sig. 0,000 \\
& $\mathrm{r}=0,557$ \\
& Sig. 0,000 \\
\hline
\end{tabular}

Sumber: Data primer yang sudah diolah (2019)

\section{H1: Ada hubungan antara kualitas} Instagram dengan kesadaran merek di kalangan pengguna Instagram Terasrumahmu di kafe English Ivy Coffee

Nilai koefisien korelasi (r) hubungan kualitas Instagram dengan kesadaran merek sebesar 0,769. Nilai koefisien korelasi (r) menunjukkan bagaimana tingkat hubungan yang dimiliki antar variabel tersebut. Pada Tabel 1 menunjukkan jika ada hubungan kualitas Instagram (X) dengan kesadaran merek (Y). Hasil korelasi jika dilihat dari tabel pedoman interpretasi koefisien korelasi 0,769 adalah kuat. Hubungan yang kuat juga ditandai dengan pengaruh yang positif karena nilai koefisien korelasi $<0,05$. Maka dapat disimpulkan hubungan variabel kualitas Instagram (X) dengan variabel kesadaran merek (Y) bersifat signifikan.

Hasil penelitian ini memberi kebaruan pada penelitian sebelumnya yang dilakukan oleh Sa'diya dengan judul "Strategi Promosi di Media Sosial Instagram terhadap Kesadaran Merek di Era Generasi Z Lailatus Sa'diya”. Hasil penelitian ini menyebutkan jika promosi yang dilakukan melalui Instagram memiliki hubungan dengan kesadaran merek. Promosi Instagram yang paling berpengaruh adalah foto dan video dan seringnya mengunggah foto dan video juga memberi pengaruh paling besar pada kesadaran merek khususnya pada generasi Z. Generasi $\mathrm{Z}$ adalah generasi internet di mana lahir pada
1995 sampai dengan 2010 sedangkan generasi Y lahir pada 1980 sampai dengan 1995 atau biasa disebut generasi transisi menuju teknologi (Rastati, 2018). Hasil penelitian tersebut memberi kebaruan bahwa tidak hanya foto dan video yang bisa mempengaruhi kesadaran merek melainkan foto yang menarik, profil yang informatif dan memilih endorser yang kredibel juga memiliki hubungan dengan kesadaran merek. Hasil penelitian ini juga menunjukkan jika generasi $\mathrm{Z}$ bukanlah generasi satu-satunya yang melek internet atau mudah dipengaruhi melalui promosi Instagram melainkan generasi $\mathrm{Y}$ juga memberi hubungan dengan kesadaran merek melalui adanya foto yang fokus dan terang, profil yang informatif maupun endorser yang kredibel. Melihat jika objek penelitian ini adalah pengguna Instagram yang berumur 17 sampai dengan 25 tahun dan masuk dalam kategori generasi Y.

\section{H2: Ada hubungan antara kualitas} konten pesan dengan kesadaran merek di kalangan pengguna Instagram Terasrumahmu di kafe English Ivy Coffee

Hasil analisis ini menguji apakah ada hubungan antara kualitas konten pesan dengan kesadaran merek. Tabel 1 menunjukkan jika ada hubungan antara kualitas konten pesan (X) dengan kesadaran merek (Y) yang memiliki korelasi 0,614 dengan signifikansi $0,000 \leq 0$, 05 yang berarti ada hubungan. Jika melihat pengaruh korelasi berdasarkan tabel pedoman interpretasi koefisien korelasi kualitas konten pesan 0,614 memiliki pengaruh kuat dengan kesadaran merek. Hasil ini mendukung penelitian yang dilakukan oleh Shojaee dan Bin Azman (Sjöberg, 2017) menyatakan kata-kata melalui elektronik memiliki korelasi positif dengan kesadaran merek. Dalam penelitian ini dimensi kualitas konten dianalis melalui dua hal yakni penggunaan foto yang menarik dan fokus maupun profil yang informatif. Hasil penelitian ini memberi kebaruan bahwa dalam menimbulkan kesadaran merek tidak hanya kata- 
kata saja yang perlu diperhatikan tetapi foto yang menarik maupun profil yang informatif juga perlu dipertimbangkan. Hal ini semakin membenarkan pernyataan Kotler (2012) jika penggunaan media sosial dapat mendongkrak kinerja bisnis karena pemasar mampu berinteraksi dengan konsumen serta membangun hubungan baik.

Kebaruan hasil penelitian ini juga menunjukkan jika dalam memunculkan kesadaran merek foto bukan satu-satunya hal yang perlu diperhatikan melainkan memperhatikan profil yang informatif juga penting karena melalui profillah keterlibatan konsumen dengan pemasar dapat terjalin. Pengambilan foto Terasrumahmu juga sangat memperhatikan ketajaman gambar maupun pencahayaan foto. Hal ini sejalan dengan pernyataan jika faktor yang membuat foto terlihat menarik adalah dengan cara pengambilan gambar, cahaya yang terang maupun menambah resolusi foto (Destriyani, Fatonah, Sutrisno, 2019) dan hal ini terlihat pada foto produk Terasrumahmu (gambar 1).

Implikasi kualitas konten pesan melalui dimensi foto secara fisik memiliki keterkaitan dengan tiga inti dari komunikasi pemasaran yang disebutkan oleh Jaieson dan Fill (2014) yaitu adanya keterlibatan, berpusat pada audiens dan adanya keberhasilan dari komunikasi pemasaran yakni biasa disebut sebagai respon kognitif.

Implikasi pertama disebutkan jika dalam komunikasi pemasaran harus adanya keterlibatan (Jamieson dan Fill, 2014). Keterlibatan audiens pada foto yang terang dan fokus dapat membuat adanya komentar maupun likes yang diberikan audiens melalui gambar yang diunggah (Nummila, 2015). Pada penelitian ini didapat hasil jika ketika pemasar dapat memperhatikan aspek seperti kualitas konten pesan dan kredibilitas endorser keterlibatan komunikasi dua arah dapat terjalin bahkan sampai kepada tahap produk semakin dikenal maupun diingat oleh konsumen. Pada dimensi foto maupun gambar yang menarik misalnya, ketika pemasar menampilkan gambar yang menarik tentu memberi pengaruh foto disukai dan adanya ketertarikan untuk memesan produk. Profil yang informatif juga memberi pengaruh adanya keterlibatan antara konsumen dengan pemasar di mana konsumen dapat dengan mudah menghubungi pemasar melalui marketplace, nomor telephone, maupun email. Penelitian ini juga membuktikan bahwa kualitas konten pesan Instagram yang terdiri dari foto dan profilmemiliki hubungan paling kuat dengan kesadaran merek jika dibandingkan dengan penggunaan endorser.

Implikasi kedua adalah komunikasi pemasaranharusberpusatpadaaudiens. Dalamhal ini pemasar dianjurkan dapat mengetahui dengan baik kebutuhan dari audiens (Jamieson dan Fill, 2014). Terasrumahmu mengunggah foto produk yang bersifat terang dan fokus maka audiens dapat melihat dengan jelas tampilan foto produk seperti warna maupun kualitas tekstur produk. Peneliti melihat jika pemasar fokus mengambil foto dengan menonjolkan kekhasan produk seperti memiliki warna monokrom yakni hitam dan putih dan juga pada produknya tertulis kalimat pendek seperti "hitam manis" seperti pada (gambar 1). Hal ini menjadi salah satu cara Terasrumahmu membangun identitas merek sehingga mampu melekat di benak konsumen.

Implikasi ketiga adalah ukuran dari keberhasilan yang ingin dicapai dalam komunikasi pemasaran yakni memenuhi kebutuhan dari setiap audiensnya (Jamieson dan Fill, 2014). Dalam mengunggah foto produk yang jelas dan fokus tentu tujuan dari Terasrumahmu adalah agar produk mampu dikenal dibenak konsumen sehingga menimbulkan adanya kesadaran merek yang top of mind.

Implikasi kualitas konten pesan melalui dimensi profil yang informatif dapat memudahkan konsumen saat mencari informasi yang di dibutuhkan (Later \& HubSpot, 2018). Profil memiliki arti penting karena dapat mewakili maupun mendukung nilai, visi dan misi dari suatu merek. Profil harus memiliki nama yang familier, mudah ditemukan melalui 
penggunaan hastag serta informatif (Nummila, 2015). Peneliti mencoba menghubungkan keterkaitan antara penggunaan profil dengan tiga inti dari komunikasi pemasaran menurut (Jamieson dan Fill, 2014) yakni terdiri dari keterlibatan, berpusat pada audiens, serta ukuran dari keberhasilan komunikasi pemasaran yakni dapat memenuhi kebutuhan dari audiens.

Implikasi pertama disebutkan jika dalam komunikasi pemasaran harus adanya keterlibatan (Jamieson dan Fill, 2014). Keterlibatan melalui adanya profil dapat terjalin ketika profil dapat menjawab informasi yang dibutuhkan oleh konsumen. Terasrumahmu menyertakan nama, katalog produk maupun link tautan yang akan menghubungan konsumen pada pemesanan produk seperti WhatsApp, Tokopedia, dan Line memudahkan konsumen bertanya maupun memesan produk. Terasrumahmu menyertakan informasi pada laman profil maka peluang kemungkinan konsumen menghubungi pemasar yang semakin besar.

Implikasi kedua adalah komunikasi pemasaran harus berpusat pada audiens. Dalam hal ini pemasar dianjurkan dapat mengetahui dengan baik kebutuhan dari audiens (Jamieson dan Fill, 2014). Menyertakan profil selengkap mungkin tidak hanya bisa mewakili nilai, visi dan misi dari suatu merek tetapi juga mampu memudahkan audiens dalam memahami dan mengenal merek. Salah satu cara pemasar ingin memenuhi kebutuhan konsumen dengan memberikan informasi yang penting seperti menyertakan katalog pemesanan maupun menyertakan nomor telephone, email, link tautan yang tentunya akan memudahkan konsumen terhubung secara langsung dengan pemasar.

Implikasi ketiga adalah ukuran dari keberhasilan yang ingin dicapai dalam komunikasi pemasaran yakni memenuhi kebutuhan dari setiap konsumennya (Jamieson dan Fill, 2014). Keberhasilan yang ingin dicapai adalah tentu mempermudah konsumen dalam mengenal identitas merek dengan tampilan
Tabel 2. Kesadaran Merek

\begin{tabular}{ccc}
\hline Tingkat & Frekuensi & $\%$ \\
\hline Top of Mind & 77 & 38.3 \\
Brand Recall & 76 & 37.8 \\
Brand Recognition & 24 & 11.9 \\
Unaware of Brand & 24 & 11.9 \\
Total & 201 & 100.0 \\
\hline
\end{tabular}

Sumber: Data primer yang sudah diolah, 2019

profil yang informatif. Pada penelitian ini didapat hasil jika konsumen dapat top of mind dengan Terasrumahmu dan kualitas konten pesan seperti foto dan profil memberi hubungan paling kuat yang berarti konsumen mengenali merek Terasrumahmu melalui adanya foto yang menarik maupun profil yang informatif.

\section{H3: Ada hubungan antara kredibilitas} endorser dengan kesadaran merek di kalangan pengguna Instagram Terasrumahmu di kafe English Ivy Coffee

Tabel 1 juga menunjukkan jika ada hubungan antara kredibilitas endorser (X) dengan kesadaran merek (Y) yang memiliki korelasi 0,557 signifikansi $0,000 \leq 0,05$ yang berarti ada hubungan. Pengaruh korelasi ini berdasarkan tabel pedoman interpretasi koefisien korelasi kredibilitas endorser 0,557 memiliki pengaruh sedang terhadap kesadaran merek. Kredibilitas endorser dianalisis berdasarkan empat komponen yaitu attractiveness, trustworthiness, expertise dan similarity. Melalui kedua dimensi tersebut dapat disimpulkan jika dimensi kualitas konten pesan memiliki pengaruh yang kuat dengan kesadaran merek karena memiliki korelasi yang lebih tinggi dibandingkan dengan kredibilitas endorser. Hasil penelitian ini juga memberi tambahan baru bagi penelitian terdahulu yang dilakukan oleh Pattra dan Datta (2014) bahwa selebriti tidak memiliki hubungan pada kesadaran merek melainkan preferensi merek dan hasil penelitian ini menunjukkan endorser atau selebriti tidak hanya menjual ketenaran saja saat mengenalkan produk melainkan penting untuk memiliki dimensi attractiveness, 
Tabel 3. Hubungan Kualitas Instagram dengan Kesadaran Merek dipengeruhi oleh Kelompok Usia

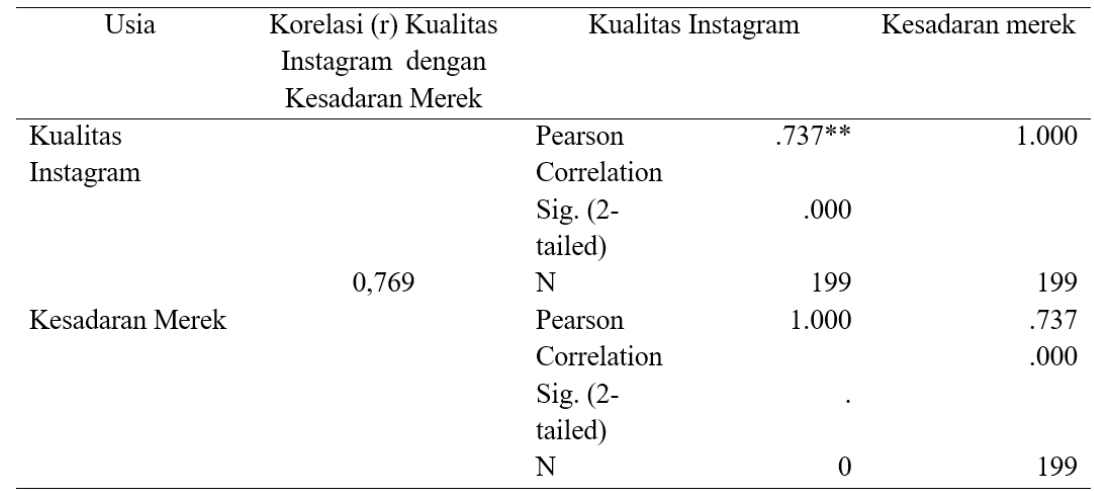

Sumber: Data primer yang sudah diolah, 2019

trustworthiness, expertise dan similirarity yang baik sehingga dapat memunculkan kesadaran merek yang top of mind bagi konsumen.

Ada salah satu teori yang menjelaskan mengenai endorser yaitu teori model pemindahan makna yang menyebutkan jika seorang celebrity endorser yang mengenalkan produk kepada konsumen sangat terbantu dengan status yang dikenal oleh masyarakat luas. Endorser yang dikenal memberikan makna pada masyarakat dan tersalurkan dalam merek atau produk (Sertoglu, Catlh, \& Korkmaz, 2014). Hasil penelitian tersebut bahwa dimensi kredibilitas endorser melalui faktor attractiveness, expertise, trustworthiness dan similarity sama-sama mempengaruhi keyakinan atau mempersuasi konsumen. Hal ini terlihat dari kredibilitas endorseryang memiliki hubungan padakesadaran merek walaupun hanya memberi hubungan yang sedang. Ketenaran seorang selebriti atau endorser tidak menjamin produk yang di pasarkan akan dikenal secara luas melainkan endorser atau selebriti juga harus memiliki kemampuan seperti attractiveness, trustworthiness, expertise dan similarity agar makna yang ditransfer kepada konsumen juga tidak hanya sekedar ketenaran yang endorser miliki tetapi juga karena memiliki kemampuan dalam mempersuasi konsumen.

Komunikasi pemasaran memiliki tiga pokok penting: keterlibatan, berpusat pada audiens, dan keberhasilan yang ingin dicapai (Jamieson dan
Fill, 2014). Berdasarkan analisis yang dilakukan peneliti terlihat bahwa pandangan Jamieson dan Fill dibenarkan oleh hasil penelitian ini. Terasrumahmu telah mampu membujuk atau mempersuasi konsumennya dengan fokus pada inti dari komunikasi pemasaran. Komunikasi pemasaran Terasrumahmu dijalankan melalui Instagram dan aspek keterlibatan, berpusat pada audiens dan keberhasilan yang ingin dicapai juga dapat dikatakan berhasil. Hal ini terlihat dari korelasi yang dihasilkan kualitas konten pesan lebih besar yakni 0,614 sedangkan dimensi kredibilitas endorser sebesar 0,557.

Tabel 2 menginformasikan bahwa responden top of mind dengan Terasrumahmu dan memiliki persentase $38 \%$, sedangkan untuk brand recall sebesar 37,8 persen dan brand recogition dan unware of brand memiliki jumlah persentase yang sama yakni $12 \%$. Hasil dari tabel 2 menunjukkan konsumen top of mind pada kualitas Instagram Terasrumahmu. Media yang dipilih oleh Terasrumahmu adalah Instagram yang terbukti mampu menjangkau konsumen sehingga terciptanya kesadaran merek yang top of mind. Kesadaran merek dapat tercapai dan diperbaiki ketika pesan yang disampaikan harus mudah diingat dan tampil beda (Durianto, 2001). Keunikan produk Terasrumahmu terlihat dari produk yang berkonsepkan monokrom dengan memiliki warna hitam dan putih maupun menggunakan kata-kata unik yang 
Tabel 4. Hubungan Kualitas Instagram dengan Kesadaran Merek dipengeruhi oleh Kelompok Jenis Kelamin

\begin{tabular}{lllrr}
\hline No $\quad \begin{array}{c}\text { Kelompok Jenis } \\
\text { Kelamin }\end{array}$ & $\begin{array}{c}\text { Korelasi (r) Kualitas } \\
\text { Instagram dengan } \\
\text { Kesadaran Merek }\end{array}$ & \multicolumn{1}{c}{ Kualitas Instagram } & \multicolumn{2}{c}{$\begin{array}{c}\text { Kesadaran } \\
\text { merek }\end{array}$} \\
1. Laki-Laki & & $\begin{array}{l}\text { Pearson } \\
\text { Correlation }\end{array}$ & $.755^{* *}$ & 1 \\
& & Sig. (2- & .000 & \\
& & tailed) & & \\
2. Perempuan & N & 83 & 83 \\
& & Pearson & $.615^{* *}$ & 1 \\
& & Correlation & .000 & \\
& & Sig. (2- & & \\
& & tailed) & & 118
\end{tabular}

Sumber: Data primer yang sudah diolah, 2019

menjadi pembeda dari produk lain. Hasil penelitian ini sejalan dengan pernyataan bahwa kesadaran merek juga perlu dibangun dengan karakter dan karisma yang kuat (Nugraha \& Wahid, 2018) sehingga tidak heran jika dalam penelitian ini Terasrumahmu mampu mencapai top of mind dalam benak konsumen.

\section{H2: Ada hubungan antara kualitas Instagram dengan kesadaran merek dipengaruhi usia}

Hasil analisis pada tabel 3 menunjukkan jika ada perubahan korelasi yang berarti usia mempengaruhi kualitas Instagram dengan kesadaran merek. Hal ini terlihat dari perubahan korelasi. Sebelum dipengaruhi usia kualitas Instagram dengan kesadaran merek memiliki korelasi sebesar 0,769 dan saat dipengaruhi usia menjadi 0,737 . Artinya bahwa ada pengaruh usia dengan hubungan kualitas Instagram dengan kesadaran merek. Penelitian yang sama dilakukan oleh Sa'diya menyebutkan generasi $\mathrm{Z}$ mampu dipengaruhi oleh promosi Instagram dengan foto dan video yang diunggah sehingga menciptakan kesadaran merek (Sa'diya, 2017). Generasi Z yang lahir pada 1995 sampai dengan 2010 dan generasi Y pada 1980 sampai dengan 1995 (Rastati, 2018). Penelitian ini memberi kebaruan bahwa generasi $\mathrm{Y}$ atau pengguna Instagram dengan umur 17-25 tahun juga memiliki pengaruh pada hubungan kualitas Instagram dengan kesadaran merek dan memiliki korelasi 0,737. Dapat disimpulkan jika generasi Y memberi pengaruh pada hubungan antara kualitas Instagram dengan kesadaran merek.

\section{H3: Ada hubungan antara kualitas} Instagram dengan kesadaran merek dipengaruhi jenis kelamin

Hasil analisis pada tabel 4 menunjukkan ada perubahan korelasi yang berarti jenis kelamin mempengaruhi kualitas Instagram dengan kesadaran merek. Hal ini terlihat dari perubahan korelasi sebelum dipengaruhi jenis kelamin kualitas Instagram dengan kesadaran merek sebesar 0,769 dan saat dipengaruhi jenis kelamin laki-laki menjadi 0,755 sedangkan jenis kelamin perempuan menjadi 0,615 . Hasil ini menunjukkan jika kelompok laki-laki memiliki korelasi lebih besar jika dibandingkan dengan korelasi kelompok perempuan yang berarti hubungan kualitas Instagram dengan kesadaran merek memberi efek lebih kuat kepada kelompok laki-laki.

Hal ini juga berkaitan dengan pernyataan Lynn dan Irwing (2002) bahwa laki-laki lebih cerdas dari perempuan hal ini dibuktikan dengan IQ laki-laki lebih tinggi dibandingkan perempuan. Temuan Irwing \& Lynn juga 
menemukan jika perempuan memiliki skor lebih tinggi di bidang fashion, tetapi laki-laki memiliki skor tertinggi secara keseluruhan. Cerdas dalam hal ini bisa saja terkait dengan kelompok lakilaki yang lebih memperhatikan dengan baik kualitas konten maupun kredibilitas endorser yang digunakan Terasrumahmu sedangkan perempuan mungkin dipengaruhi dengan faktor lain yang tidak diteliti dalam penelitian ini.

Terasrumahmu telah berhasil melakukan komunikasi pemasaran melalui Instagram. Dimensi yang telah digunakan seperti kualitas konten pesan dan kredibilitas endorser menjadi cara mempersuasi dan membujuk konsumen. Kualitas konten pesan memiliki hubungan paling kuat dengan kesadaran merek yang berarti foto dan profil Terasrumahmu sangat membantu responden mengenali dan mengingat produk dibenaknya atau top of mind. Penelitian ini juga semakin memperkuat pernyataan bahwa media sosial sangat membantu mendongkrak kinerja bisnis (Kotler,2012) asalkan tetap memperhatikan aspek-aspek penting dan memanfaatkan fitur yang ada, salah satu contohnya seperti gambar atau foto sebelum diunggah di Instagram dapat diedit terlebih dahulu agar gambar yang hendak diunggah lebih terang dan menarik untuk dilihat.

\section{Simpulan}

Bersadarkan hasil uji hipotesis penelitian ini menunjukkan bahwa Model Pemindahan Makna teruji pada populasi pengguna Instagram Terasrumahmu di kafe English Ivy Coffee. Instagram mampu menjadi media pemasaran yang menjangkau konsumen sehingga memberikan kesadaran merek yang top of mind. Pada penelitian ini didapat hasil adanya hubungan antara kualitas Instagram dengan kesadaran merek. Kualitas Instagram lebih didominasi oleh dimensi kualitas konten pesan yang terdiri dari foto dan profil yang memiliki korelasi lebih besar yakni 0,614 sedangkan kredibilitas endorser memiliki korelasi 0,557.
Peneliti juga mendapatkan hasil jika usia memiliki korelasi 0,737 dan dalam hal ini terlihat jika generasi $\mathrm{Y}$ atau pengguna Instagram yang berumur 17-25 tahun juga memberi pengaruh pada hubungan antara kualitas Instagram dengan kesadaran merek. Jenis kelamin laki-laki memiliki korelasi 0,755 sedangkan jenis kelamin perempuan memiliki korelasi 0,615. Hasil korelasi ini menunjukkan jika kelompok lakilaki lebih memberi pengaruh pada hubungan antara kualitas Instagram dengan kesadaran merek jika dibandingkan dengan perempuan.

Penelitian ini memberi kebaruan bahwa kesuksesan dalam menggunakan Instagram tidak hanya bisa dibangun dari adanya keterlibatan antara pemasar dengan konsumen saja maupun hanya mengandalkan dengan seringnya memposting foto dan video melainkan dengan memperhatikan cara pengambilan gambar, memanfaatkan fitur-fitur dalam Instagram seperti memperhatikan warna gambar, ketajaman gambar yang akan diunggah di Instagram. Ketenaran atau status yang dimiliki oleh seorang endorser juga tidak menjamin produk yang ditawarkan diingat oleh konsumen melainkan perlu mempertimbangkan aspek seperti attractiveness, trustworthiness, expertise dan similarity karena keempat hal ini sangat membantu konsumen top of mind pada merek yang dipasarkan.

Hasil penelitian ini juga diharapkan memberi kontribusi bagi usaha clothing Terasrumahmu bahwa dalam menciptakan kesadaran merek yang top of mind dibenak konsumen kualitas konten pesan dan penggunaan endorser tidaklah cukup melainkan perlu mempertimbangkan aspek karekteristik konsumen seperti usia dan jenis kelamin. Jika target sasaran Terasrumahmu laki-laki maka sangat penting membangun kualitas foto, profil dan pemilihan endorser yang lebih menarik, karena hasil penelitian ini menunjukkan laki-laki lebih mendominasi memiliki pengaruh pada hubungan antara kualitas Instagram dengan kesadaran merek. 
Jika perempuan maka perlu memperhatikan dari aspek lain yang tidak diteliti dalam penelitian ini. Penelitian ini juga menunjukkan jika kesadaran merek ternyata tidak hanya berlaku pada produk yang luxury atau high end. Terasrumahmu menjadi salah satu contoh merek lokal yang juga mampu memberikan kesadaran merek pada konsumen, tentunya dengan tetap memperhatikan setiap aspek seperti kualitas konten, menggunakan endorser yang kredibel maupun memperhatikan karakteristik konsumen.

\section{Daftar Pustaka}

Arniawati, A., Sutrisno, I., \& Rochayanti, C. (2015). Kajian Komunikasi Pemasaran Badan Pengelola Desa Wisata Bobung dalam Meningkatkan Jumlah Wisatawan. Jurnal Ilmu Komunikasi, 13(1), 96-108. Diakses dari http://jurnal.upnyk.ac.id/ index.php/komunikasi/article/view/1452

Bell, E. (2012). How the Popularity of a Sport Affects the Use of Atheletes in Print Advertisement: A Content Analysis Using the Meaning Transfer Model. Thesis. US: University of South Alabama.

Destriyani, R., Fatonah, S., \& Sutrisno, I. (2019). Effective Promotion Strategies of Javafood in Attracting Instagram Audience. The Indonesian Journal of Communication Studies, 12(1), 2839. Diakses dari http://jurnal.upnyk. ac.id/index.php/ijcs/article/view/2996

Dewi, W. W. A., \& Avicenna, F. (2019). Social Media Marketing: Consumer Behavior on The Cruelty Free Concern of Beauty Brand. Jurnal Ilmu Komunikasi, 17(1), 95106. Diakses dari http://jurnal.upnyk.ac.id/ index.php/komunikasi/article/view/2379

Durianto. (2001). Strategi Menaklukkan Pasar Melalui Riset Ekuitas dan Perilaku Merek. Jakarta: PT Gramedia Pustaka Utama.

Fauzi, V. P., \& Lubis, E. E. (2016). Pemanfaatan Instagram sebagai Social Media Marketing Er-corner Boutique dalam Membangun Brand
Awareness di Kota Pekanbaru. JOM FISIP, 3(1),1-15. Diakses darihttps://jom.unri.ac.id/ index.php/JOMFSIP/article/view/9366 Jamieson dan Fill. (2014). Marketing Communication. UK: Edinburgh Business School. Kotler P. (2012). Marketing Management. Pearson Education International. Later \& HubSpot. (2018). Instagram for Business in 2018. Using Instagram Stories, Carousels, Ads, Influencers, and More!. Cambridge, Massachusetts: Later \& HubSpot. Lynn, R., \& Irwing, P. (2002). Sex Differences in General Knowledge, Semantic Memory and Reasoning Ability. British Journal of Psyhology, 93(4), 545-556. https:// doi.org/10.1348/000712602761381394 Machfoedz, M. (2010). Komunikasi Pemasaran Modern. Yogyakarta: Cakra Ilmu Imprint Gelar Semesta Aksara. Miller \& Allen (2012). How Does Celebrity Meaning Transfer? Investigating the Process of Meaning Transfer with Celebrity Affiliates and Mature Brands. Journal of Consumer Psychology, 22(3), 443-452. https://doi.org/10.1016/j.jcps.2011.11.001. Nugraha, Y. A., \& Wahid, U. (2018). New Wave Marketing dalam Membangun Brand Equity di Era Digital. Jurnal Ilmu Komunikasi, 16(2), 158-171. Diakses dari http://jurnal.upnyk.ac.id/index.php/ komunikasi/article/view/3005/2418 Nummila, Mia. (2015). Successful Social Media Marketing on Instagram Case: @minoshoes. Thesis. Finland: HaagaHelia University of Applied Science O'Keefe, D.J. (2016). Persuasion and Social Influence. In The International Encyclopedia of Communication Theory and Philosophy (eds K.B. Jensen, E.W. Rothenbuhler, J.D. Pooley and R.T. Craig). doi:10.1002/9781118766804.wbiect067 Pattra, S., \& Datta, S. K. (2014). Competence of Bollywood Celebrities in Generating Brand Recall in Kolkata. In Vrontis, 
$\mathrm{D}$ and Weber, $\mathrm{Y}$ and Tsoukatos, E (Ed), Future of Entrepreneurship. 1422-1439. Euromed Press. Pertiwi, W. K. (2018). Riset Ungkap Pola PemakaianMedsos OrangIndonesia. Diambil 25April2019,darihttps://tekno.kompas.com/ $\mathrm{read} / 2018 / 03 / 01 / 10340027 /$ riset-ungkappola-pemakaian-medsos-orang-indonesia

Putri. (2018). Strategi Promosi Instagram Paling Hits Tahun 2018 Bagi Para Starup. Retrieved from https://digitalentrepreneur. id/strategi - promosi - instagram/ Rastati, R. (2018). Media Literasi Bagi Digital Natives: Perspektif Generasi Z di Jakarta. Jurnal Kwangsan: Jurnal Teknologi Pendidikan, 6(1), 60-73. https://doi. org/10.31800/jurnalkwangsan.v6i1.72

Roy, S., Jain \& Rana, P. (2013). The Moderating Role of Consumer Personality and Source Credibility in Celebrity Endorsement. Asia-Pacific Journal of Business Administration, 5(1), 72-88. https:// doi.org/10.1108/17574321311304549

Sa'diya, L. (2017). Strategi Promosi di Media SosialInstagramterhadapKesadadaranMerek di Era Generasi Z. Competence: Journal of Management Studies, 11(2), 186-195. https:// doi.org/10.21107/kompetensi.v11i2.3530 Seiter \& Gass. (2003). Perspective on Persuasion, Social Influence, and Compliance Gaining. Cancer Research. Retrieved from http://psychology.uchicago.edu/people/ faculty/cacioppo/jtcreprints/prbc04.pdf
Sertoglu, A. E., Cath, O., \& Korkmaz, S. (2014). Examining the Effect of Endorser Credibility on the Consumer's Buying Intentions: An Empirical Study in Turkey. International Review of Management and Marketing, 4(1), 66-77. Diakses dari https://www.econjournals.com/ index.php/irmm/article/view/666 Setiawan,W.(2017).EraDigitaldanTantangannya. Bandung : Universitas Pendidikan Indonesia. Silalahi. (2015). Metode Penelitian Sosial Kuantitatif. Bandung: PT Refika Aditama. Sjöberg, A. (2017). Influencing Brand Awareness through Social Media. Thesis International Business Management. Arcada, 1-82. Stephanie, E. (2013). Pengaruh Kredibilitas Endorser Terhadap Minat Beli Melalui Sikap Atas Iklan Pada Produk Shampo L'oreal Di Surabaya. CALYPTRA, 2(2), 1 - 21. Diakses dari https://journal.ubaya. ac.id/index.php/jimus/article/view/714 Sugiyono. (2016). Metode Penelitian Manajemen. Bandung: ALFABETA. Yudhiartika, D., \& Haryanto, J. O. (2012). Pengaruh Personal Selling, Display, Promosi Penjualan terhadap Kesadaran Merek dan Intensi Membeli pada Produk Kecantikan Pond's. Buletin Studi Ekonomi, 17(2), 142-156. Diakses dari https://ojs. unud.ac.id/index.php/bse/article/view/2187 